\title{
Comparative neurotoxicity of iobitridol with iohexol by intracisternal administration in Wistar rats
}

\section{Neurotoxicidade comparativa do iobitridol com o iohexol, por via intracisternal, em ratos Wistar}

\author{
Fabíola Peixoto da Silva Mello ${ }^{1 *}$; Rafael Stedile ${ }^{1}$; Aline Silva Gouvêa ${ }^{1}$; \\ Clarissa Boemler Hollenbach ${ }^{1}$; Eduardo Conceição de Oliveira²; \\ Fernanda Bastos de Mello ${ }^{3}$ J João Roberto Braga de Mello ${ }^{4}$
}

\begin{abstract}
Iobitridol is a tri-iodinated contrast agent, and neurotoxicologic studies of the intracisternal administration are scarce and inconclusive. The purpose of this study was to compare the neurotoxicity of iobitridol with iohexol, by intracisternal administration in Wistar rats, for a pre-clinical evaluation of its use as a myelographic agent. The animals, a total of 75 , were divided into three experimental groups, iobitridol, iohexol and cerebral artificial fluid (control group), with 25 animals per group. Then, these were divided into five subgroups of five animals each, and given doses of 200, 400, 600, 800 and $1000 \mathrm{mg} \mathrm{kg}^{-1}$, while the control group received the equivalent volumes of contrast media tested. The animals were evaluated after 5, 15, 30, 60, 120, 180 and $240 \mathrm{~min}$ of intracisternal administration of these substances, for signs of depression and excitement, tactile palmar grasp, flexor, extensor, palpebral, papillary and pinna reflexes, surface righting and placing reactions, and with an auditory startle test. The evaluations were assessed daily for seven days with these parameters and their body weight, food, and water intake were also measured. There were no statistically significant differences between groups tested with respect to any of the evaluated parameters. In other words, in this animal model, the iobitridol demonstrated a low neurotoxicologic potential, comparable to that observed with iohexol. Further study with dogs and cats, as an alternative, is suggested.
\end{abstract}

Key words: Contrast media. Cistern. Iodinated contrast. Myelography. Toxicity.

\section{Resumo}

O iobitridol é um meio de contraste tri-iodado, e estudos referentes à neurotoxicidade, com administração subaracnóide são escassos e inconclusivos. O objetivo deste trabalho foi comparar a neurotoxicidade do iobitridol com a do iohexol, por via intracisternal, em ratos Wistar, como avaliação pré-clínica da utilização deste como agente mielográfico. Foram utilizados 75 animais divididos em três grupos experimentais com 25 animais: iobitridol, iohexol e líquido cerebroespinhal artificial (grupo controle). Estes foram subdivididos em cinco subgrupos com cinco animais cada, com doses distintas de 200, $400,600,800$ e $1000 \mathrm{mg} \mathrm{kg}^{-1}$, sendo utilizado no grupo controle o volume equivalente aos meios de contraste testados. Os animais foram avaliados após 5, 15, 30, 60, 120, 180 e 240 min da administração intracisternal dessas substâncias, quanto a sinais de depressão e excitação, reflexos tátil de agarramento

\footnotetext{
${ }^{1}$ Pesquisadores, Universidade Federal do Rio Grande do Sul, UFRGS, Porto Alegre, RS, Brasil. E-mail: fabiola.mello@ufrgs.br; stediler@gmail.com; aline.gouvea@bol.com.br; clarissa.hollenbach@gmail.com

2 Prof., Universidade de Caxias do Sul, UCS, Caxias do Sul, RS, Brasil, E-mail:eduvetrs@yahoo.com.br

${ }^{3}$ Prof ${ }^{a}$, Universidade Federal de Ciências da Saúde de Porto Alegre, UFCSPA, Porto Alegre, Brasil. E-mail: fernanda.mello@ ufrgs.br

${ }^{4}$ Prof., UFRGS, Porto Alegre, Brasil. E-mail: jmello@gabinete.ufrgs.br

* Author for correspondence
} 
palmar, flexor, extensor, palpebral, pupilar e da pina, reação de endireitamento e posicionamento e resposta auditiva. Nos sete dias subsequentes, os animais foram avaliados diariamente quanto a estes parâmetros, e ainda a massa corporal, a ingestão de ração e de água, foram mensuradas. Não foram observadas diferenças estatisticamente significativas entre os grupos testados com meios de contraste, em nenhum dos parâmetros avaliados. Dessa forma, nesse modelo animal, o iobitridol demonstrou baixa neurotoxicidade, comparável a observada com o iohexol. Sugerem-se mais estudos com cães e gatos para utilização do iobitridol como alternativa.

Palavras-chave: Cisterna. Contraste iodado. Meio de contraste. Mielografia. Toxicidade.

\section{Introduction}

Iodinated contrast media $(\mathrm{CM})$ are radiopaque substances, and although iohexol and ioversol are considered safe in myelography routine, adverse events associated with their use are observed, such as seizures, muscle spasms, nausea, vomiting, apnea, and dyspnea (SARMENTO et al., 2000; RODACKI et al., 2014).

Iobitridol is another tri-iodinated CM. Its molecular design was obtained after research on the configuration, distribution, and permanent nature of its hydrophilic structure (BETTMAN, 1996). Iobitridol, like iohexol, ioversol and iopamidol, is a monomer and nonionic, with low molecular weight and a high degree of hydrophilicity (DENCAUSSE et al., 1995; LEFEVRE et al., 1996; TUDURY et al., 1997). It is characterized by a high level of dimensional stability due to the hydrophilic groups around the tri-iodinated lipophilic benzene ring and considered an efficient CM with few adverse reactions from its intravenous use in humans (PETERSEIN et al., 2003; MCCORMACK, 2013). Its leaflet indicates intravenous use, but does not have an indication for subarachnoid use. Existing studies are scarce and inconclusive concerning its neurotoxicity in intracisternal (IC) administration.

The objective of this study was to evaluate the neurotoxicity of iobitridol via IC administration in rats and compare it to iohexol.

\section{Material and Methods}

A total of 75 male Wistar rats, 90 to 120 days old and weighing $340 \mathrm{~g} \pm 70 \mathrm{~g}$, from a laboratory breeding center, were used. The animals were kept in the experimental laboratory with constant humidity conditions $(50 \pm 20 \%)$, temperature (22 \pm $2{ }^{\circ} \mathrm{C}$ ) and under a 12-h on/off light cycle (08:30 to 20:30). The initial period of acclimatization of the animals was 14 days.

In this double blinded study, animals were randomly distributed into three experimental groups, with 25 animals per group. One group for each CM, iobitridol (300 mg ml-1) and iohexol $\left(300 \mathrm{mg} \mathrm{ml}^{-}\right.$ ${ }^{1}$ ), and a control group (artificial cerebrospinal fluid - ACF). Each treatment group (iobitridol, iohexol and ACF) was divided into five subgroups with five animals each. In the groups that received the CM via IC administration, each subgroup received a different dose equivalent to $200,400,600,800$, and $1000 \mathrm{mg} \mathrm{kg}^{-1}$. The control group received a sterile ACF solution at a volume equivalent to those used in the CM groups, with volumes ranging from 0.9 to $1.3 \mathrm{ml}$, via the same route of administration.

For the administration of the CM and ACF, the rats were anesthetized with isoflurane, initially in an anesthetic chamber which was subsequently maintained via a mask. They were then placed in a stereotaxic and with use of ear bars, the angle between the head and the body was kept at $90^{\circ}$. A needle gauge of $0.45 \times 13 \mathrm{~mm}$ was introduced 1 $\mathrm{mm}$ cranially to the midpoint between the occipital bone and the axis spinous process, at a depth between 5.5 and $6.5 \mathrm{~mm}$, according to body weight (LEBEDEV et al., 2004), with the correct depth verified by the efflux of cerebrospinal fluid. After aspirating 0.04 to $0.06 \mathrm{ml}$ of cerebrospinal fluid, a new prefilled syringe was attached with the volume of the substance (iobitridol, iohexol or ACF) to be 
used, all pre-heated in a water bath at $37^{\circ} \mathrm{C}$ before application. The manual administration rate was approximately $0.05 \mathrm{ml} \mathrm{s}^{-1}$.

After administration, and still anesthetized with isoflurane via a mask, the animals were kept in the same position for one minute, without the removal of the needle. Then, they were removed from the stereotaxic and maintained for one more minute with digital compression at the application site. Radiographs were taken for confirmation of the presence of contrast medium in the subarachnoid space (Figure 1). After, the animals were put back in boxes and subsequently evaluated for signs of depression, excitement, reflexes (tactile palmar grip, flexor extensor, palpebral, pupillary, and pinna), righting responses, and auditory responses at 5, 15,
$30,60,120,180$, and 240 min after the injection, and thereafter once a day for seven days. The signs of depression were scored as: $0=$ animal is sniffing, sitting up spontaneously, and responding to touch; $1=$ disorientation and/or apathy and/or slowness of movement; 2 = immobile, but responsive to touch; $3=$ paresis and/or immobile or unresponsive. The signs of excitement were classified with the scores: $0=$ animal is sniffing, sitting up spontaneously, and responding to touch; $1=$ irritability and/or hyperreflexia; 2 = partial seizures; $3=$ generalized seizures (SOVAK et al., 1980; SUNDGREN et al., 1995; MALY et al., 1995). In the case of death, information about the time between contrast administration and the occurrence of death was recorded, and then the animals were sent for necropsy.

Figure 1. Radiographic image after intracisternal administration of the contrast media to verify the absence of a leakage.

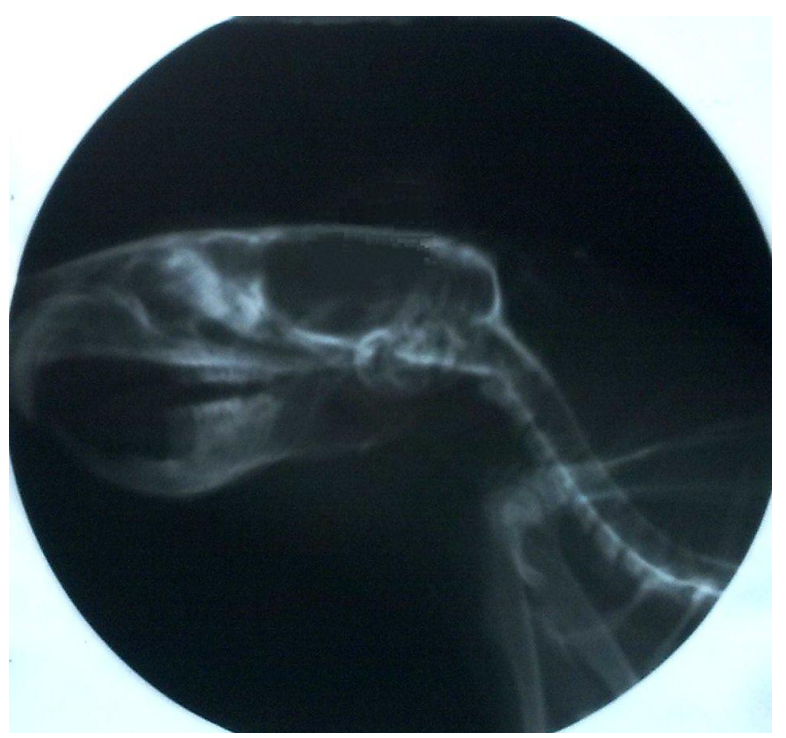

Body weight, feed, and water consumption were measured daily from the day of the procedure for seven days. Animals and feed were weighed on an analytical balance. After measuring the feed, it was restored up to a weight of $200 \mathrm{~g}$. The volume of water consumed was measured in a beaker and subsequently filled up again to obtain a total volume of $500 \mathrm{ml}$.
On the eighth day of the experiment, the rats were euthanized for necropsy. The cerebrum, cerebellum, and cervical, thoracic, and lumbar spinal cord were removed from all experimental animals and analyzed macroscopically for signs of bleeding or color change in the central nervous system. In addition, two animals per subgroup, besides those that died during the procedure, were randomly submitted to histopathology in the university pathology sector, in 
order to assess possible circulatory, inflammatory, or degenerative changes.

All experimental procedures were approved by the Research Ethics Committee (CEUA / Federal University of Health Science of Porto Alegre) under the 148/14 protocol number.

For the statistical analysis of association between the doses and variables, and the drugs and the variables, we used the chi-square test and Fisher's exact test. For variables related to the influence of different substances and doses, on body mass, and ingestion of water and feed, we used an analysis of variance (ANOVA) for repeated measures. These analyses were performed using SPSS 18 and EXCEL programs, with a confidence interval of $95 \%$. A value of $\mathrm{p}<0.05$ was considered statistically significant.

\section{Results and Discussion}

Neurotoxicity can be measured by several parameters that depend on the CM, mode of administration, and animal used (CAILLE; ALLARD, 1988). The lack of homogeneity between data from studies evaluating the potential toxicity of the $\mathrm{CM}$ has been related to variations of the individuals in the sample, contrast administration site, gender, race, clinical disease, and number of administrations (LEWIS; HOSGOOD, 1992; BARONE et al, 2002). Thus, the standardization of variables and homogeneity can be obtained with the use of rats as the experimental model.

The radiographs confirmed the location of the contrast medium in the subarachnoid space, without any signal of leakage at the application site.

Statistically significant differences between groups tested with the CM, in any of the evaluated parameters, were not observed.

Deaths occurred in five experimental animals, including three animals using the iobitridol and two with iohexol, four of them at the two highest doses. All deaths occurred after apnea, during or up to 2 min after the application of the substance. Similar to data found in this study, regarding the interval between administration of the CM and death, there is an article using in the same species comparing iohexol and other CMs, where all deaths occurred immediately after injection (RALSTON et al., 1989). However, there are other articles reporting up to $4 \mathrm{~h}$ (LUZZANI et al., 1996), and varying between $10 \mathrm{~min}$ to $24 \mathrm{~h}$ after administration (WIBLE et al., 1995).

Differences related to the number of deaths and time elapsed until death, when comparing to other authors, may be related to methodology. These include, rat contention for cisterna magna puncturing (to carry out the pilot of this work, we tried the technique described by Jeffers and Griffith (1942), apud Waynforth and Flecknell (1992), and by Melartin et al. (1970), however, when performing the radiography control, a significant extravasation of CM through the subarachnoid space was found), the concentration of the CM used (higher iodine concentrations reflected an increase in osmolality and consequent increased risk of side effects) (FATONE et al., 1997), the anesthetic protocol used (this can affect the respiratory depression; such as isoflurane, which has a direct influence on medullar ventilation center and indirect effect on the intercostal muscles), the rate of administration (hasty administration can cause the CM to flow into the rostral subarachnoid space accumulating in the fourth ventricle and cerebellar hemisphere, increasing the intracranial pressure, indicated by clinical signs including bradycardia and apnea that are related to a reduction of cerebral blood flow) (LEITE et al., 2002; ARANY-TÓTH et al., 2013) and preheating the $\mathrm{CM}$ (with a rise of temperature, there is a viscosity reduction) (UCHIYAMA et al., 2006).

Tables 1 and 2 shows the signs of depression and excitement, respectively, observed from $5 \mathrm{~min}$ to the application of the substance (iohexol, iobitridol or ACF) in five different doses. 
Table 1. Percentage of rats with signs of depressive behavior during the period from 5 to 60 minutes after intracisternal administration of the substance: iohexol (IOH), iobitridol (IOB), and control group (C). The doses administered were 200, 400, 600, 800, and $1000 \mathrm{mg} \mathrm{kg}^{-1}$ and their corresponding volumes were used for the C. Depression score: $0=$ animal is sniffing, sitting up spontaneously and responding to touch; disorientation and/or apathy and/or slowness of movement; 2 = immobile, but responsive to touch; 3 = paresis and/or immobile or unresponsive. There was no statistically significant difference between the tested groups $(\mathrm{p}>0.05)$.

\begin{tabular}{|c|c|c|c|c|c|c|c|c|c|c|c|c|}
\hline \multicolumn{13}{|c|}{$200 \mathrm{mg} \mathrm{kg}^{-1}$} \\
\hline Time & \multicolumn{3}{|c|}{$5 \mathrm{~min}$} & \multicolumn{3}{|c|}{$15 \mathrm{~min}$} & \multicolumn{3}{|c|}{$30 \mathrm{~min}$} & \multicolumn{3}{|c|}{$60 \mathrm{~min}$} \\
\hline $\begin{array}{l}\text { Subst. } \\
\text { Score }\end{array}$ & $\mathrm{IOH}$ & IOB & $\mathrm{C}$ & $\mathrm{IOH}$ & IOB & $\mathrm{C}$ & $\mathrm{IOH}$ & IOB & $\mathrm{C}$ & $\mathrm{IOH}$ & IOB & $\mathrm{C}$ \\
\hline 0 & 60 & 60 & 60 & 60 & 60 & 100 & 80 & 80 & 100 & 80 & 80 & 100 \\
\hline 1 & 40 & 40 & 40 & 40 & 40 & & 20 & 20 & & 20 & 20 & \\
\hline 2 & & & & & & & & & & & & \\
\hline 3 & & & & & & & & & & & & \\
\hline Death & & & & & & & & & & & & \\
\hline
\end{tabular}

\begin{tabular}{|c|c|c|c|c|c|c|c|c|c|c|c|c|}
\hline \multicolumn{13}{|c|}{$400 \mathrm{mg} \mathrm{kg}^{-1}$} \\
\hline Time & \multicolumn{3}{|c|}{$5 \mathrm{~min}$} & \multicolumn{3}{|c|}{$15 \mathrm{~min}$} & \multicolumn{3}{|c|}{$30 \mathrm{~min}$} & \multicolumn{3}{|c|}{$60 \mathrm{~min}$} \\
\hline $\begin{array}{l}\text { Subst. } \\
\text { Score }\end{array}$ & $\mathrm{IOH}$ & IOB & $\mathrm{C}$ & $\mathrm{IOH}$ & IOB & $\mathrm{C}$ & $\mathrm{IOH}$ & IOB & $\mathrm{C}$ & $\mathrm{IOH}$ & IOB & $\mathrm{C}$ \\
\hline 0 & 60 & 40 & 40 & 100 & 60 & 100 & 100 & 80 & 100 & 100 & 80 & 100 \\
\hline 1 & 20 & 40 & 60 & & 20 & & & & & & & \\
\hline \multicolumn{13}{|l|}{2} \\
\hline 3 & 20 & & & & & & & & & & & \\
\hline Death & & 20 & & & 20 & & & 20 & & & 20 & \\
\hline \multicolumn{13}{|c|}{$600 \mathrm{mg} \mathrm{kg}^{-1}$} \\
\hline Time & \multicolumn{3}{|c|}{$5 \mathrm{~min}$} & \multicolumn{3}{|c|}{$15 \mathrm{~min}$} & \multicolumn{3}{|c|}{$30 \mathrm{~min}$} & \multicolumn{3}{|c|}{$60 \mathrm{~min}$} \\
\hline $\begin{array}{l}\text { Subst. } \\
\text { Score }\end{array}$ & $\mathrm{IOH}$ & $\mathrm{IOB}$ & $\mathrm{C}$ & $\mathrm{IOH}$ & $\mathrm{IOB}$ & $\mathrm{C}$ & $\mathrm{IOH}$ & IOB & $\mathrm{C}$ & $\mathrm{IOH}$ & IOB & $\mathrm{C}$ \\
\hline 0 & 20 & 40 & 40 & 80 & 60 & 80 & 60 & 80 & 100 & 100 & 100 & 100 \\
\hline 1 & 80 & 60 & 60 & 20 & & 20 & & 20 & & & & \\
\hline 2 & & & & & 40 & & 40 & & & & & \\
\hline 3 & & & & & & & & & & & & \\
\hline Death & & & & & & & & & & & & \\
\hline
\end{tabular}

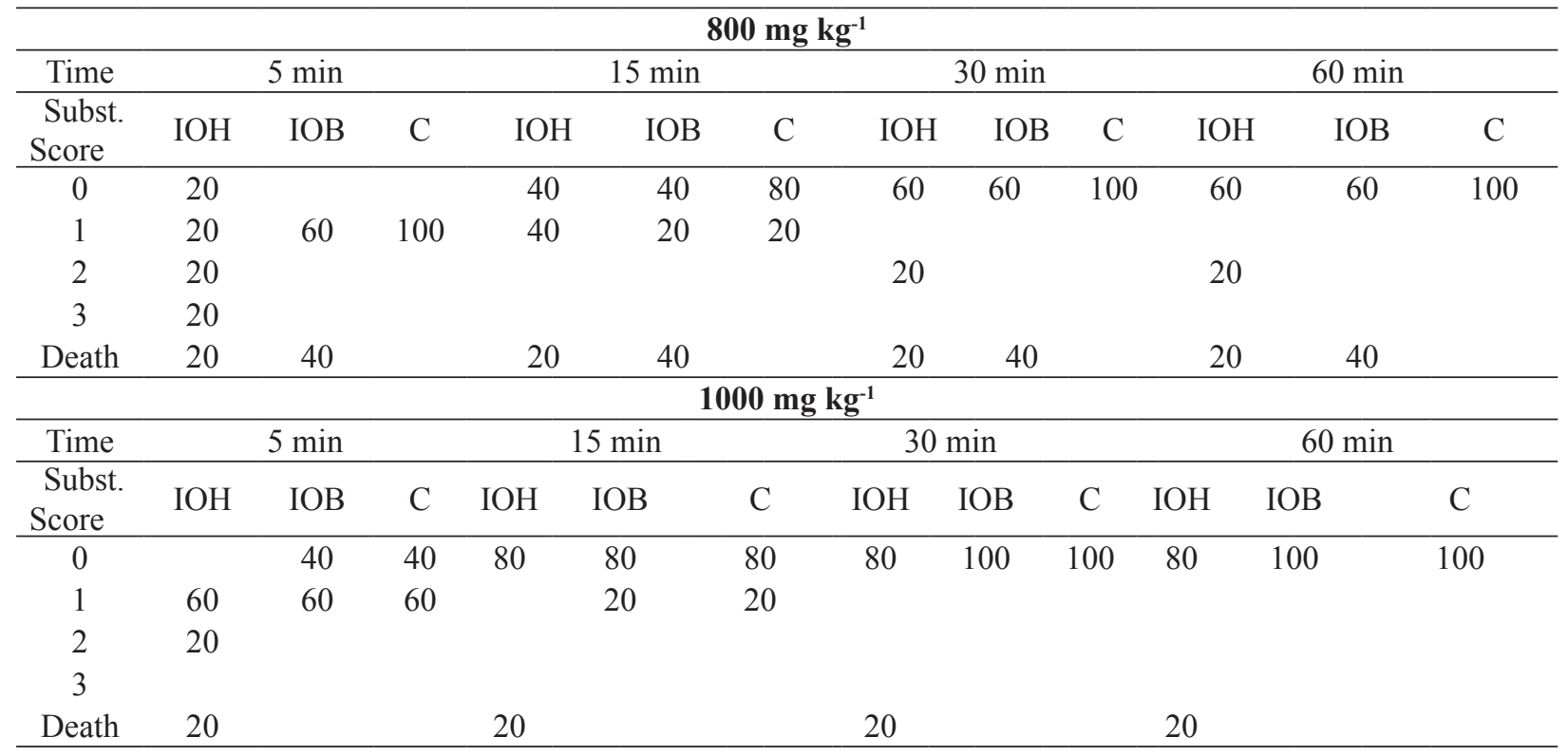


Table 2. Percentage of rats with signs of excited behavior during the period from 5 to 60 minutes after intracisternal administration of the substance: iohexol (IOH), iobitridol (IOB), and control group (C). The doses administrated were 200, 400, 600, 800, and $1000 \mathrm{mg} \mathrm{kg}^{-1}$ and their corresponding volumes were used in the $\mathrm{C}$. Excitation score: $0=$ animal is sniffing, sitting up spontaneously and responding to the touch; $1=$ irritability and/or hyperreflexia; $2=$ partial seizures; 3 = generalized seizures There was no statistically significant difference between the tested groups $(\mathrm{p}>0.05)$.

\begin{tabular}{|c|c|c|c|c|c|c|c|c|c|c|c|c|}
\hline \multicolumn{13}{|c|}{$200 \mathrm{mg} \mathrm{kg}^{-1}$} \\
\hline Time & \multicolumn{3}{|c|}{$5 \mathrm{~min}$} & \multicolumn{3}{|c|}{$15 \mathrm{~min}$} & \multicolumn{3}{|c|}{$30 \mathrm{~min}$} & \multicolumn{3}{|c|}{$60 \mathrm{~min}$} \\
\hline $\begin{array}{l}\text { Subst. } \\
\text { Score }\end{array}$ & $\mathrm{IOH}$ & IOB & $\mathrm{C}$ & $\mathrm{IOH}$ & IOB & $\mathrm{C}$ & $\mathrm{IOH}$ & IOB & $\mathrm{C}$ & $\mathrm{IOH}$ & IOB & $\mathrm{C}$ \\
\hline 0 & 60 & 80 & 100 & 60 & 80 & 100 & 100 & 100 & 100 & 100 & 100 & 100 \\
\hline 1 & 40 & 20 & & 40 & 20 & & & & & & & \\
\hline 2 & & & & & & & & & & & & \\
\hline 3 & & & & & & & & & & & & \\
\hline Death & & & & & & & & & & & & \\
\hline
\end{tabular}

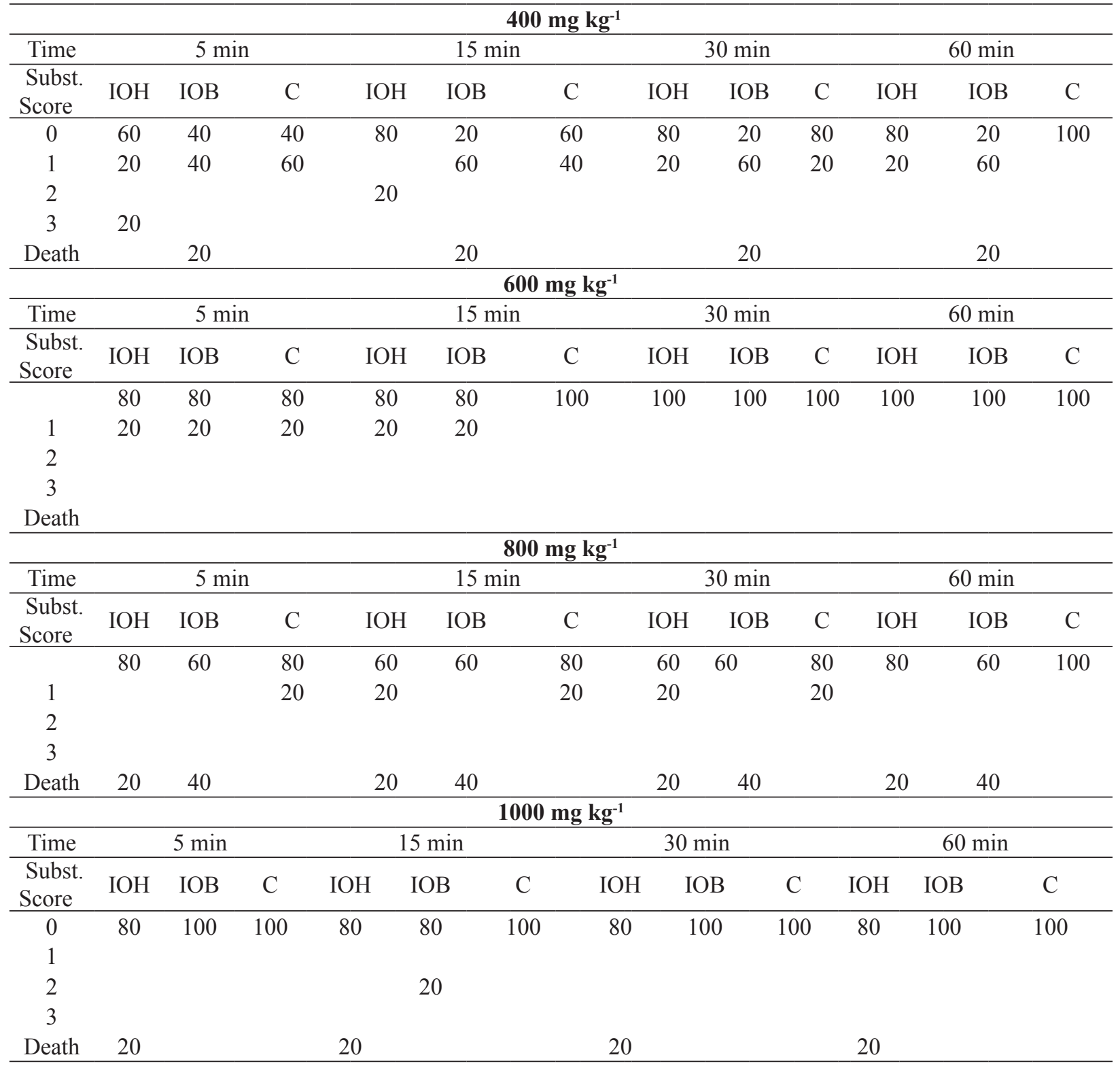


Despite the iohexol group being the only group to show signs of depression with immobility and unresponsiveness (a score of 3), no statistically significant difference between the groups tested was observed. Signs of depression are described as a toxic response to the CM (RALSTON et al., 1989). Previous reports compared the depressant effects of $\mathrm{CM}$ in rats. These include, the IC administration of iopamidol and iohexol, which led to greater hypoactivity by iopamidol (according to the technique described by Melartin et al., 1970 apud WIBLE et al., 1995); iomeprol, iopamidol, iohexol, ioversol, iopentol, iopromide, iofratol, iotrolan, and iodixanol, administered by the same route in rats (according to the technique described by Jeffers and Griffith, 1942 apud LUZZANI et al., 1996); and intracerebroventricular administration in mice, which resulted in nervous system depression (sedation, shortness of breath, prostration, and reduction in motor activity) with some episodes of seizures (LUZZANI et al., 1996).

Excitation responses were observed with both iobitridol and iohexol, and involved irritability, hyperreflexia, and seizures. Signs of irritability and/or hyperreflexia were observed in 17 animals, involving both the $\mathrm{CM}$ and control groups. Similar signals have already been cited with the IC administration of iohexol, ioversol, iopamidol, and metrizamide in rats, such as hyperactivity, grooming, and chewing movements; but they did not report the incidence in each group tested separately (RALSTON et al., 1989). Muscle tremors associated with the CM use have been attributed to irritative temporary and localized effects (TUDURY et al., 1997). However, the use of volatile anesthetics have been associated with changes in EEGs, seizures, and abnormal muscle activity in humans and other species (LERVIK et al., 2010). Thus, the influence of isoflurane cannot be ruled out since it was used in all groups, including the control group.

There were only two cases of seizure: one generalized, occurring in one animal of the iohexol group at a dose of $400 \mathrm{mg} \mathrm{kg}^{-1}$, while the other was focal and affected only the muscles of the face, in the iobitridol group at the maximum tested dose $\left(1000 \mathrm{mg} \mathrm{kg}^{-1}\right)$. Between the application and the occurrence of seizures, it occurred 5 and $15 \mathrm{~min}$ after administration, respectively, and persisted for a few seconds. In previous studies using rats, such as Wible et al. (1995) and Luzzani et al. (1996), this fact was not mentioned. In rabbits, the onset of seizures was observed between 5 and 60 min after injection of the substance was completed (MALY et al., 1995). The findings of this study seem to reflect the neurotoxic effect of iobitridol and iohexol, as seizures are commonly reported as neurotoxic effects of CMs, especially when the applications are made through the cisterna magna (LEITE et al., 2002). Other potential causative factors include, an increased duration of anesthesia (this was greater in the animals where higher doses of CM were used, in order to maintain the administration rate), an increased intracranial pressure (which can contribute to the reduction of cerebral circulation and lead to the development of neurological complications after the application of the CM) (ARANY-TÓTH et al., 2013), and the anesthetic protocol used (LEITE et al., 2002).

Excitatory signals were also observed in studies of iohexol and iopamidol in dogs, including temporal and facial muscle fasciculation, neck muscle rigidity, and seizures (FATONE et al., 1997).

Among the reflexes and test answers, the ones that remained absent for more than 30 min were: the tactile reflex palmar grip, in the iohexol group $\left(800 \mathrm{mg} \mathrm{kg}^{-1}\right.$ ) for up to $24 \mathrm{~h}$ after the procedure; the palpebral reflex, which showed disturbance in all groups and was absent in some animals over 24 $\mathrm{h}$, with two cases lasting for four days, involving one animal in the iohexol group $\left(600 \mathrm{mg} \mathrm{kg}^{-1}\right)$ and the other in the iobitridol group (1000 $\left.\mathrm{mg} \mathrm{kg}^{-1}\right)$; and auditory responses, in the iobitridol group $(600 \mathrm{mg}$ $\mathrm{kg}^{-1}$ ) there was no auditory response after $60 \mathrm{~min}$, which persisted for at least $4 \mathrm{~h}$, and persisted in the iohexol group at $\left(600 \mathrm{mg} \mathrm{kg}^{-1}\right)$ for at least $2 \mathrm{~h}$. 
Absences of reflexes and test responses may indicate a neurotoxic effect of iohexol and iobitridol, except for the palpebral reflex. This decreased as the volume administered increased, which appears to be related to an increase of intracranial pressure. Two reasons for this may be that the clinical signs observed dispersed among the groups, including the control group, and that paralysis of the seventh pair of cranial nerves is described in patients with increased intracranial pressure (POLLOCK; WONG, 2008). Despite the absence of palpebral reflex lasting longer in some animals, compared to the other tested reflexes, there was a return of normal conditions in a maximum of four days. There is no way to make comparisons with the experiments carried out in the references consulted, regarding the reflex tests, since there is no description in the literature for the evaluation and comparison of radiological CMs.

Nausea and vomiting are adverse effects observed after subarachnoid administration of iohexol and other CM in humans (CARROLL et al., 1997). The use of iohexol in dogs has also been associated with vomiting (SARMENTO et al., 2000). In order to estimate the nausea, malaise, and discomfort of these animals, the body mass and percentage consumption of food and water were measured daily during the seven-day observation period, but there were not any statistically significant differences. Similar results were previously reported, comparing the body mass of rats using iobitridol and iohexol via intrathecal routes (DONADIEU et al., 1996), however they used doses of $380 \mathrm{mg} \mathrm{kg}^{-1}$, wherein this study, smaller and larger doses were used to more effectively compare the neurotoxicity between these two drugs.

No changes were revealed from the macroscopic and histopathological examinations. This finding is similar to that previously observed by other authors (LARSEN et al., 1995; LUZZANI et al., 1996). Since, in this experiment, the animals that died during the procedure were necropsied after about $4 \mathrm{~h}$, and the collected material preserved in formalin, there may not have been signs of chemical meningitis or other changes related to increased intracranial pressure. This is due to an insufficient amount of time necessary to attract inflammatory cells, thus edema occurs which leads to signal degeneration or necrosis.

Neurotolerability of the nonionic CM appears less dependent on the physicochemical characteristics of the pharmaceutical formulations of the $\mathrm{CM}$ and more on their chemical structure, which is what certain receptors recognize. The key factor for neurotoxicity is the binding capacity of the $\mathrm{CM}$ to neuronal membranes, and the intracellular concentration (LUZZANI et al., 1996; PATSIKAS, 1999). The iobitridol formula is based on balanced hydrophilicity and unlike iohexol, its molecule has a limited strain capacity in contact with hydrophilic membranes, which should reduce the number of adverse reactions (DENCAUSSE et al., 1995; DONADIEU et al., 1996; MCCORMACK, 2013; TROCHERIE et al., 2005). However, there was no statistically significant difference between the groups tested.

\section{Conclusion}

It was concluded that in this animal model, iobitridol was shown to have comparable neurotoxicity with iohexol, since there was no statistically significant difference between the groups tested. More studies are recommended in dogs and cats before iobitridol can be indicated as a myelographic agent.

\section{Acknowledgment}

Coordenação de Aperfeiçoamento de Pessoal de Nível Superior (CAPES). 


\section{References}

ARANY-TÓTH, A.; CSÉBI, P.; REICZIGEL， J.; SÉRE, V; NÉMETH, T. Subarachnoid pressures and cardiorespiratory parameters during cisternal myelography in isoflurane anaesthetized dogs. Veterinary Anaesthesia and Analgesia, Malden, v. 40, n. 4, p. 390398, 2013.

BARONE, G.; ZIEMER, L. S.; SHOFER, F. S.; STEINBERG, S. A. Risk factors associated with development of seizures after use of iohexol for myelography in dogs: 182 cases (1998). Journal of American Veterinary Medicine Association, Schaumburg, v. 220, n. 10, p. 1499-1502, 2002.

BETTMAN, L. A. Xenetix - a milestone in diagnostic imaging. Acta Radiologica, Estocolmo, v. 37, n. 6, p. 1-2, 1996. Supplement 400.

CAILlE, J. M.; ALLARD, M. Neurotoxicity of hydrosoluble iodine contrast media. Investigative Radiology, Philadelphia, v. 23, p. S210-S212, 1988. Supplement 1.

CARROLL, G. L.; KEENE, B. W.; FORREST, L. J. Asystole associated with iohexol myelography in a dog. Veterinary Radiology \& Ultrasound, Oxford, v. 38, n. 4, p. 284-287, 1997.

DENCAUSSE, A.; CHAMBON, C.; VIOLAS, X.; BONNEMAIN, B. Comparative study of the dialysability of iobitridol and iohexol in the rat with impaired renal function. Acta Radiologica, Estocolmo, v. 36, n. 5, p. 545-548, 1995.

DONADIEU, A. M.; IDEE, J. M.; DOUCET, D.; LEGROS, A.; PENATI, S.; NAIN-DIT-DUCRET, M.; MARMION, F.; BONNEMAIN, B. Toxicologic profile of iobitridol, a new nonionic low-osmolality contrast medium. Acta Radiologica, Estocolmo, v. 37, p. 17-24, 1996. Supplement 400.

FATONE, G.; LAMAGNA, F.; PASOLINI, M. P.; POTENA, A.; BRUNETTI, A. Myelography in the dog with non-ionic contrast media at different iodine concentrations. Journal of Small Animal Practice, Quedgeley, v. 38, n. 7, p. 292-294, 1997.

LARSEN, L. E.; HEGLUND, I. F.; FABIAN, R.; WALDAY, P.; BLAZAK, F. Neural tolerability of iodixanol in mice and dogs after single and repeated intracisternal administration. Acta Radiologica, Estocolmo, v. 36, p. 238-43, 1995. Supplement 399.

LEBEDEV, S. V.; BLINOV, D. V.; PETROV, S. V. Spatial characteristics of cisterna magna in rats and novel technique for puncture with a stereotactic manipulator. Bulletin of Experimental Biology and Medicine, Moscou, v. 137 , n. 6 , p. $35-638,2004$.

LEFEVRE, T.; FUNCK, F.; ALIOT, E.; ETHEVENOT, B. Safety and efficacy of the new iodinated nonionic low-osmolality contrast medium iobitridol (Xenetix) in coronary and ventricular angiography. Acta Radiologica, Estocolmo, v. 37, p. 75-80, 1996. Supplement 400.

LEITE, A. V.; NUNES, N.; REZENDE, M. L. Anestesia para mielografia em cães. Ciência Rural, Santa Maria, v. 32, n. 4, p. 725-729, 2002.

LERVIK, A.; HAGA, H. A.; BECKER, M. Abnormal motor activity during anaesthesia in a dog: a case report. Acta Veterinaria Scandinavica, London, v. 52, n. 1, p. 52-64, 2010.

LEWIS, D. D.; HOSGOOD, G. Complications associated with the use of iohexol for myelography of the cervical vertebral column in dogs: 66 cases (1988-1990). Journal of American Veterinary Medicine Association, Schaumburg, v. 200, n. 9, p. 1381-1384, 1992.

LUZZANI, F.; MORISETTI, A.; BUSSI, S.; TIRONE, P.; HAEN, C. Neurotolerability of nonionic x-ray contrast media - the role of chemotoxicity. Investigative Radiology, Philadelphia, v. 31, n. 6, p. 338-344, 1996.

MALY, P. SUNDGREN, P.; BAATH, L.; WALDAY, P. Neural tolerance of the non-ionic dimmers iodixanol and iotrolan and the non-ionic monomer iopamidol during myelography in non-anaesthetised rabbits. Acta Radiologica, Estocolmo, v. 36, n. 6, p. 644-648, 1995.

MCCORMACK, P. L. Iobitridol - a review of its use as a contrast medium in diagnostic imaging. Clinical Drug Investigation, Auckland, v. 33, n. 2, p. 155-166, 2013.

MELARTIN, E.; TUOHIMAA, P. J.; DABB, R. Neurotoxicity of iothalamates and diatrizoates: I. Significance of concentration and cation. Investigative Radiology, Philadelphia, v. 5, n. 1, p. 13-21, 1970.

PATSIKAS, M. N.; KOUTINAS, A. VLEMAS, I.; POLIZOPOULOU, Z.; MUSTARDAS, N.; TZEGAS, S.; DESSIRIS, A. K. Absence of cerebrospinal fluid abnormalities and spinal cord lesions after iotrolan cervical myelography in normal cats: an open placebocontrolled study. Journal of Veterinary Medicine, Malden, v. 46, n. 8, p. 453-457, 1999.

PETERSEIN, J.; PETTERS, C. R.; WOLF, M; HAMM, $B$. Results of the safety and efficacy iobitridol in more than 61.000 patients. European Radiology, Berlin, v. 13, n.8, p. 2006-2011, 2003.

POLLOCK, M.; WONG, T. CNS trauma: increased ICP diagnosis. In: MODAK, R. K. (Ed.). Anesthesiology keyword review. Philadelphia: Lippincott Williams \& Wilkins, 2008. p. 109-110. 
RALSTON, W. H.; ROBBINS, M. S.; COVENEY, J. BLAIR, M. Acute and subacute toxicity of ioversol in experimental animals. Investigative Radiology, Philadelphia, v. 24, p. S2-S9, 1989. Supplement 1.

RODACKI, M.; VILLANOVA JR., J. A.; TASQUETI, U. I.; PIMPÃO, C. T.; PRADO, A. M. B. Epidemiological aspects of myelography in dogs: 61 cases (2003-2012). Semina: Ciências Agrárias, Londrina, v. 35, n. 6, p. 3191-3204, 2014.

SARMENTO, L. V. C.; TUDURY, E. A.; ALBUQUeRQUE, E. R.; MAGALhÃES, P. K. L. Mielografia em cães e gatos- revisão. Clínica Veterinária, São Paulo, v. 26, n. 5, p. 23-32, 2000.

SOVAK, M.; SIEFERT, H. M.; RANGANATHAN, R. Combined methods for assessment of neurotoxicity: testing of new nonionic radiographic media. Investigative Radiology, Philadelphia, v. 15, n. 1, p. S248-S253, 1980.

SUNDGREN, P.; BAATH, L.; MALY, P. CNS- effects from subarachnoid injections of iohexol and the nonionic dimmers iodixanol and iotrolan in the rabbit. Acta Radiologica, Estocolmo, v. 36, n. 3, p. 307-311, 1995.

TROCHERIE, S., ALAOUI, F. IDÉE. J. M. SANTUS, R.; COURT, L. Electrocorticographic evaluation of iobitridol a nonionic contrast medium, during selective cerebral arteriography in rabbits. American Journal of Neuroradiology, Oak Brook, v. 16, n. 8, p. 1635-1642, set. 2005.
TUDURY, E. A.; ARIAS, M. V. B.; CAMARGO, P. L.; FARIA, M. L. E.; MACHADO, C. E. G. Meio de contraste ioversol em neuroradiologia canina. Ciência Rural, Santa Maria, v. 27, n. 4, p. 619-623, 1997.

UCHIYAMA, Y.; ABE, T.; TANAKA, N.; KOJIMA, K.; UCHIDA, M.; HIROHATA, M.; HAYABUCHI, N. Factors contributing to blood-brain barrier disruption following intracarotid injection of nonionic iodinated contrast medium for cerebral angiography: experimental study un rabbits. Radiation Medicine, Tokio, v. 24, n. 5, p. 321-326, 2006.

WAYNFORTH, H. B.; FLECKNELL, P. A. Administration of substances. In: _. Experimental and surgical technique in the rat. San Diego: Academic Press, 1992. p. 1-67.

WIBLE, J. H. JR.; BARCO, S. J.; SHERRER, D. E.; WOJDYLA, J. K.; ADAMS, M. D. Neurotoxicity of non-ionic x-ray contrast media after intracisternal administration in rats. European Journal of Radiology, Philadelphia, v. 19, n. 3, p. 206-211, 1995. 